\title{
Angiotensin-Converting Enzyme Activity May Predict Disease Severity in Psoriasis
}

\author{
Matilde Bandeira ${ }^{1,2, *} \mathbb{0}$, Ângela Gil ${ }^{3,4,5}$, Ana Carolina Santos ${ }^{3,4,5}$, Vasco C. Romão ${ }^{1,2} \mathbb{D}$, \\ Mário Rui Mascarenhas 5,6 , Paulo Filipe ${ }^{7,8,9}$, João Eurico Fonseca ${ }^{1,2}$ and Manuel Bicho ${ }^{3,4,5}$ (i)
}

\section{check for}

updates

Citation: Bandeira, M.; Gil, Â.;

Santos, A.C.; Romão, V.C.;

Mascarenhas, M.R.; Filipe, P.;

Fonseca, J.E.; Bicho, M.

Angiotensin-Converting Enzyme

Activity May Predict Disease Severity

in Psoriasis. Rheumato 2022, 2, 15-23.

https://doi.org/10.3390/

rheumato2010003

Academic Editor: Bruce M

Rothschild

Received: 9 January 2022

Accepted: 10 February 2022

Published: 14 February 2022

Publisher's Note: MDPI stays neutral with regard to jurisdictional claims in published maps and institutional affiliations.

Copyright: (C) 2022 by the authors. Licensee MDPI, Basel, Switzerland. This article is an open access article distributed under the terms and conditions of the Creative Commons Attribution (CC BY) license (https:// creativecommons.org/licenses/by/ $4.0 /)$
1 Rheumatology Department, Hospital de Santa Maria, Centro Hospitalar Universitário Lisboa Norte, Lisbon Academic Medical Centre, 1649-035 Lisbon, Portugal; vascoromao@gmail.com (V.C.R.); jcfonseca@medicina.ulisboa.pt (J.E.F.)

2 Rheumatology Research Unit, Instituto de Medicina Molecular, Lisbon Academic Medical Centre, 1649-035 Lisbon, Portugal

3 Laboratório de Genética, Faculdade de Medicina da Universidade de Lisboa, 1649-035 Lisbon, Portugal; angela_gil@live.com.pt (Â.G.); carolinasantos@medicina.ulisboa.pt (A.C.S.); manuelbicho@medicina.ulisboa.pt (M.B.)

4 Instituto de Investigação Científica Bento da Rocha Cabral, 1250-047 Lisbon, Portugal

5 Instituto de Saúde Ambiental-Ecogenética e Saúde Humana, Faculdade de Medicina da Universidade de Lisboa, 1649-035 Lisbon, Portugal; mascarenhasmr@gmail.com

6 Clínica de Endocrinologia, Diabetes e Metabolismo de Lisboa, 1050-017 Lisbon, Portugal

7 Dermatology Department, Centro Hospitalar Universitário Lisboa Norte, 1649-035 Lisbon, Portugal; paulolealfilipe@gmail.com

8 Unidade Curricular de Dermatologia, Faculdade de Medicina da Universidade de Lisboa, 1649-035 Lisbon, Portugal

9 Dermatology Research Unit, Instituto de Medicina Molecular, Lisbon Academic Medical Centre, 1649-035 Lisbon, Portugal

* Correspondence: bandeira.matilde@gmail.com

\begin{abstract}
Psoriasis is a multifactorial disease, with many genetic risk factors, one of which seems to be the angiotensin-converting enzyme (ACE) insertion/deletion (I/D) polymorphism. ACE activity has been shown to be higher in psoriatic patients and it suggests an oxidative stress state, as seen in many cardiovascular disorders. We aimed to explore the association between ACE activity and polymorphisms and cardiovascular risk amongst psoriatic patients. We included 64 psoriatic patients and 1091 controls and compared ACE I/D polymorphism genotype and serum activity for both groups. ACE genotypes were similar in psoriatic patients and controls. Notably, serum ACE activity was higher in psoriatic patients $(19.09 \pm 2.86 \mathrm{U} / \mathrm{mL})$ compared to controls $(11.85 \pm 0.40 \mathrm{U} / \mathrm{mL})$, $p=0.015$. Non-HDL cholesterol was significantly lower in II polymorphism $(p=0.037)$. Psoriatic activity (PASI) was associated with a higher cardiovascular risk estimated by lower HDL concentrations $(r=-0.496, p=0.007)$, and higher triglyceride levels $(r=0.421, p=0.020)$ and TC/HDL and LDL/HDL ratios $(r=0.612, p<0.001$ and $r=0.437, p=0.023$, respectively). Patients with psoriasis have higher ACE activity levels, independent of ACE genotype. Moreover, disease activity correlated with cardiovascular risk. This could support the eventual role of ACE as a possible biomarker for disease severity and cardiovascular risk in psoriasis patients.
\end{abstract}

Keywords: angiotensin-converting enzyme; ACE; psoriasis; cardiovascular risk; lipid profile; HDL; LDL; cholesterol

\section{Introduction}

Psoriasis affects approximately $2 \%$ of the population worldwide. It has a multifactorial etiology and physiopathology where immune, environmental factors and multiple genes play an interacting role $[1,2]$.

Previous studies have shown an increment in angiotensin-converting enzyme (ACE) activity in patients with psoriasis [3] which decreases to identical levels as controls after 
treatment for psoriasis [4]. Because of the changes seen in ACE levels in psoriatic patients, polymorphisms in its coding gene have been studied in this population. However, studies have been conflicting, showing either no association between the ACE I/D polymorphism and the disease [5], or contradictory results regarding which genotype is associated with risk for psoriasis [6-10].

The ACE gene is located on chromosome 17q23 and has a polymorphism defined by the insertion (I) or deletion (D) of a $287 \mathrm{bp}$ non-coding Alu repeat sequence [11]. Higher serum ACE levels were found in DD homozygotes, with this polymorphism accounting for $47 \%$ of the variability in ACE levels [12]. Serum ACE can be assessed regarding its levels as well as its activity concerning a specific substrate. Despite ACE levels and activity being strongly linked, in the presence of ACE modulators, enzyme activity may be a more relevant parameter [13-16].

Psoriatic patients may have an accompanying joint inflammatory disease (Psoriatic Arthritis) in a third of cases. In addition, they may have a higher prevalence of numerous comorbidities, being particularly relevant the higher incidence of cardiovascular diseases, which is directly related to the severity of psoriasis $[17,18]$. Psoriasis should therefore be perceived not only as an exclusively dermatologic condition, but also as a chronic systemic disease most frequently manifested by skin lesions [19].

The pathophysiology of psoriasis involves expansion and activation of Th1, Th17 and Th22 cells subsets, antigen presenting cells and the subsequent cytokines [20,21]. These Th1 and Th17 cascades are common to atherosclerosis. In fact, similar inflammatory cell infiltrates may be found within both psoriatic lesions and atherosclerotic plaques [22].

Triglyceride, total cholesterol (TC), and LDL-cholesterol levels were found to be higher in psoriatic patients [23,24]. Notably, this was reported even since the onset of the disease [25], giving way to the possibility that dyslipidemia may precede the onset of psoriasis. It is, however, unclear whether these lipid profile changes are simply a reflection of the increased incidence of obesity in psoriatic populations [26] and its consequent influence on lipid metabolism. Both entities, obesity and psoriasis, share common inflammatory pathways, involving, for instance, TNF and IL6 [27]. These pro-inflammatory molecules are released by adipocytes and have been shown to increase cardiovascular risk [28] and to affect free fatty acids, cholesterol, and lipid levels [29]. HDL particle characteristics may influence cardiovascular risk in psoriasis patients [30,31]. A lower HDL efflux capacity was found in psoriatic patients, which is associated with non-calcified coronary atherosclerosis, regardless of HDL levels [32].

Higher ACE levels suggest an oxidative stress state which is present in many cardiovascular disorders and is, in fact, one of the precipitating factors for atherogenesis [33,34]. Accordingly, the ACE gene DD genotype was found to be associated with an increased risk of left ventricular hypertrophy [35]. Likewise, both the DD and the ID genotypes have shown significant associations with the development of coronary artery disease [36].

Our main goal was to explore associations between ACE activity, its polymorphisms, and the presence and activity of psoriasis presence and severity. Furthermore, we aimed to assess whether ACE influences the association between psoriasis and cardiovascular disorders.

\section{Materials and Methods}

\subsection{Studied Populations}

We recruited 64 psoriatic patients attending the Dermatology department in Hospital de Santa Maria-Centro Hospitalar Universitário Lisboa Norte. 1091 non-psoriatic controls were recruited from two different clinical sites: Instituto Português do Sangue and Clínica de Endocrinologia, Diabetes e Metabolismo de Lisboa Lda, after due written consent. Patients with systemic inflammatory diseases were excluded from this arm of the study.

In both groups, demographic characteristics, TC, HDL, LDL, and triglycerides were assessed, as well as ACE activity and I/D polymorphism. In addition, in the psoriatic group, disease activity was measured using the Psoriasis Area and Severity Index (PASI). 


\subsection{DNA and Enzyme Activity Determination}

Both populations' blood samples were collected and stored at $-20^{\circ} \mathrm{C}$ for further analysis. DNA extraction, quantification and amplification were performed using a modified salting out method, the NanoDrop spectrophotometer (ND-2000, Thermo Scientific, Lisbon, Portugal), the polymerase chain reaction (PCR) with specific primers for the ACE polymorphism and the Applied Biosystems 2720 thermal cycler to amplify the DNA fragment in question.

These products were separated by electrophoresis with an agarose gel previously stained with ethidium bromide. The fragments were then observed using UV-fluorescence in a transilluminator Genosmart VWR. An analysis of the results was performed using a molecular marker containing $50 \mathrm{pb}$ Invitrogen and a negative control consisting of a 10uL volume of deionized water with no DNA. The conditions in which these analyses were performed are displayed in Table 1.

Table 1. Conditions of the DNA amplification and electrophoresis used to determine the genotype for the ACE I/D polymorphism.

\begin{tabular}{ccccc} 
& PCR Conditions & PCR Components & Gel Conditions & Genotypes \\
\hline & 35 cycles & DNA: $10 \mathrm{uL}(200 \mathrm{mg})$ & & \\
ACE I/D & Denaturation: $45 \mathrm{~s}$ at $94{ }^{\circ} \mathrm{C}$ & Primer F: $1 \mathrm{uL}, 10 \mathrm{pmol}$ & $2 \%$ & $\mathrm{II}-477 \mathrm{pb}$ \\
Polymorphism & Annealing: $45 \mathrm{~s}$ at $58^{\circ} \mathrm{C}$ & Primer R: $1 \mathrm{uL}, 10 \mathrm{pmol}$ & $110 \mathrm{volts}$ & $\mathrm{ID}-477+190 \mathrm{pb}$ \\
& Extension: $45 \mathrm{~s}$ at $72{ }^{\circ} \mathrm{C}$ & Master Mix: $12.5 \mathrm{uL}$ & $60 \mathrm{~min}$ & $\mathrm{DD}-190 \mathrm{pb}$ \\
& Final extension: $32 \mathrm{~s}$ at $72{ }^{\circ} \mathrm{C}$ & Dimethyl sulfoxide: $1.25 \mathrm{uL}$ & & \\
\hline
\end{tabular}

The enzyme activity was determined by recording the decrease in absorbance of furylacryloyl-phenylalanyl-glycyl-glycine (FAPGG) at $346 \mathrm{~nm}$ for $15 \mathrm{~min}$ at $37^{\circ} \mathrm{C}$, since ACE also mediates this substrate's cleavage. This method is adapted from Faure-Delanef et al. in 1998, using Lambert-Beer law [17].

\subsection{Statistical Analysis}

Both groups were checked for the Hardy-Weinberg equilibrium regarding genotype frequency and controls were found to be distributed according to the equilibrium $\left(\chi^{2}=0.718, p=0.698\right)$ as well as the psoriatic population $\left(\chi^{2}=0.204, p=0.903\right)$.

In order to estimate an association between psoriasis activity and cardiovascular risk, two subgroups of psoriatic patients were defined, considering that PASI $\leq 10$ accounts for mild activity and PASI $>10$ includes both moderate to severe disease activity [37].

All populations were tested for a normal distribution using the Kolmogorov-Smirnov test and analysed accordingly. Descriptive statistics were displayed as mean \pm standard error of mean (number of cases) or number (percentage). Univariate analysis with continuous variables was performed using a $t$-test or Mann-Whitney $U$ test, as appropriate. Categorical variables were analysed with a chi-square or Kruskal Wallis test. The correlation between numeric variables was assessed using Spearman or Pearson's correlation test, as appropriate. We conducted a multivariate regression analysis to adjust for variables of interest and potential confounders, such as sex. The statistically significant difference was predetermined as $p<0.05$ for all analyses. All statistical analyses were conducted using IBM SPSS Statistics $24^{\circledR}$.

\section{Results}

The population of this study was comprised of 64 psoriatic patients with a mean age of $52.2 \pm 12.9$ years and 30\% males. The control group $(n=1091)$ had a mean age of $54.9 \pm 13.7$ years and $76.7 \%$ males. Since the two groups displayed a significant difference in sex frequency, all tests comparing the two populations were either performed separately or done as a multivariate regression to adjust for this variable. Both groups were shown 
to have similar age distributions ( $t$-test, $p=0.136$ ), and no major adjustment was thus required.

Comparison of ACE genotypes showed no significant difference between patients and controls (Table 2). DD was the most common followed by ID with II being the rarer genotype. The allele frequency was also similar in both groups, with a majority presenting a D allele.

Table 2. Frequencies of ACE polymorphism and alleles: \% (number of cases).

\begin{tabular}{cccc}
\hline & & Psoriatic Patients & Controls \\
\hline \multirow{2}{*}{$\begin{array}{c}\text { ACE I/D polymorphism } \\
p=0.777\end{array}$} & II & $11.5(7)$ & $13.3(59)$ \\
\cline { 2 - 4 } & ID & $41.0(25)$ & $43.8(194)$ \\
\hline $\begin{array}{c}\text { ACE allele } \\
p=0.480\end{array}$ & DD & $47.5(29)$ & $42.9(190)$ \\
\hline
\end{tabular}

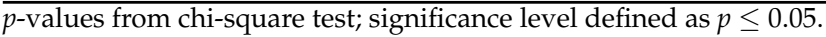

Serum ACE activity, on the other hand, was found to be significantly higher in psoriatic patients compared with control subjects (Table 3), even when adjusting for sex. ACE activity was also shown to be different for each of its genotypes $(\mathrm{H}(2)=24.148, p<0.001)$. Subjects with a DD genotype had higher serum ACE activity, an intermediate level of ACE activity was found in the ID population, and subjects with an II genotype displayed a smaller mean activity (Table 4). We thus used multivariate linear regression to adjust for ACE genotype and sex, and found that ACE activity was significantly higher in psoriatic patients, independent of both of these co-variates ( $\mathrm{B}=6.564, \mathrm{CI} 95 \% 3.183-9.944, p<0.001)$.

Table 3. ACE activity: mean \pm standard error of mean (number of cases).

\begin{tabular}{|c|c|c|c|c|c|}
\hline & & Psoriatic Patients & Controls & $\begin{array}{l}\text { Univariate } \\
\text { ( } p \text {-Value) }\end{array}$ & Multivariate * \\
\hline \multirow{3}{*}{ ACE activity } & Total & $19.09 \pm 2.86(20)$ & $11.85 \pm 0.40(276)$ & $p=0.015$ & \multirow{3}{*}{$\begin{array}{c}\mathrm{B}=6.618, \mathrm{CI} 95 \% \\
3.176-10.060 \\
p<0.001\end{array}$} \\
\hline & Female & $17.38 \pm 3.13(6)$ & $11.62 \pm 0.44(220)$ & $p=0.037$ & \\
\hline & Male & $19.83 \pm 3.92(14)$ & $12.76 \pm 0.93(56)$ & $p=0.063$ & \\
\hline
\end{tabular}

$p$-values from $t$-test or Mann-Whitney test according to the distribution of the samples; significance level defined as $p \leq 0.05$; adjusted for sex with a multivariate linear regression.

Table 4. ACE activity for each ACE genotype: mean \pm standard error of mean (number of cases).

\begin{tabular}{|c|c|c|c|}
\hline & & ACE Activity & \\
\hline \multirow{3}{*}{$\begin{array}{c}\text { ACE I/D } \\
\text { polymorphism }\end{array}$} & II & $7.75 \pm 0.67(24)$ & \multirow{3}{*}{$p<0.001$} \\
\hline & ID & $11.27 \pm 0.56(101)$ & \\
\hline & DD & $14.57 \pm 0.90(93)$ & \\
\hline \multirow{3}{*}{ Post-hoc tests } & \multicolumn{2}{|c|}{ II-ID } & $p=0.003$ \\
\hline & \multicolumn{2}{|c|}{ II-DD } & $p<0.001$ \\
\hline & \multicolumn{2}{|c|}{ ID-DD } & $p=0.005$ \\
\hline
\end{tabular}

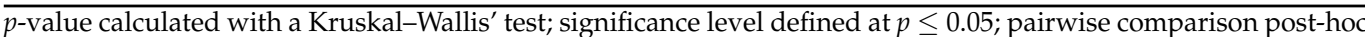
tests displayed.

A correlation was found between ACE activity and LDL/HLD ratio ( $\mathrm{r}=0.133, p=0.048)$. No other correlation between this enzyme's activity and different cholesterol measures (data not shown) was found to be significant in our population.

Using the dichotomization between patients with PASI $>10$ and PASI $\leq 10$, a significant difference in lipid profile features, namely HDL cholesterol, TC/HDL ratio, and 
triglyceride levels was shown (Table 5, Figure 1). PASI was inversely correlated with HDL cholesterol $(\mathrm{r}=-0.496, p=0.007)$ and positively correlated with LDL/HDL ratio $(\mathrm{r}=0.437$, $p=0.023)$ and triglyceride levels $(\mathrm{r}=0.421, p=0.020)$. PASI was also strongly correlated with TC/HDL ratio $(\mathrm{r}=0.612, p<0.001)$ (Figure 2$)$.

Table 5. Means for the different parameters of the lipid profile and ACE activity between patients with different psoriasis severity: mean \pm standard error of mean (number of cases).

\begin{tabular}{ccccc}
\hline & PASI $\leq \mathbf{1 0}$ & PASI $>\mathbf{1 0}$ & Univariate $(p$-Value $)$ & Multivariate * $(p$-Value $)$ \\
\hline Total cholesterol & $196.60 \pm 46.20(20)$ & $196 \pm 38.42(9)$ & $p=0.814$ & $p=0.447$ \\
\hline HDL cholesterol & $54.26 \pm 14.72(19)$ & $41.67 \pm 11.04(9)$ & $p=0.028$ & $\begin{array}{c}\mathrm{B}=-12.596, \text { CI 95\% } \\
-23.987--1.206, p=0.032\end{array}$ \\
\hline TC/HDL ratio & $3.76 \pm 0.89(19)$ & $4.88 \pm 1.02(9)$ & $p=0.012$ & $\begin{array}{c}\mathrm{B}=0.792, \mathrm{CI} 95 \% \\
0.025-1.560, p=0.044\end{array}$ \\
\hline Non-HDL cholesterol & $143.74 \pm 39.51(19)$ & $154.78 \pm 32.57(9)$ & $p=0.279$ & $p=0.257$ \\
\hline LDL cholesterol & $121.42 \pm 37.41(19)$ & $121.13 \pm 36.60(8)$ & $p=0.811$ & $p=0.547$ \\
\hline LDL/HDL ratio & $2.31 \pm 0.69(19)$ & $3.01 \pm 0.89(8)$ & $p=0.035$ & $p=0.059$ \\
\hline Triglycerides & $113.38 \pm 66.66(21)$ & $163.56 \pm 44.95(9)$ & $p=0.021$ & $\mathrm{~B}=50.175$, CI 95\% \\
\hline ACE activity & $10.24 \pm 8.22(5)$ & $17.20 \pm 11.03(4)$ & $p=0.327$ & $0.187-100.162, p=0.049$ \\
\hline
\end{tabular}

$p$-values were calculated with $t$-test or Mann-Whitney test according to the distribution of the samples; significance level defined at $p \leq 0.05$; *adjusted for sex and age, through multivariate linear regression.
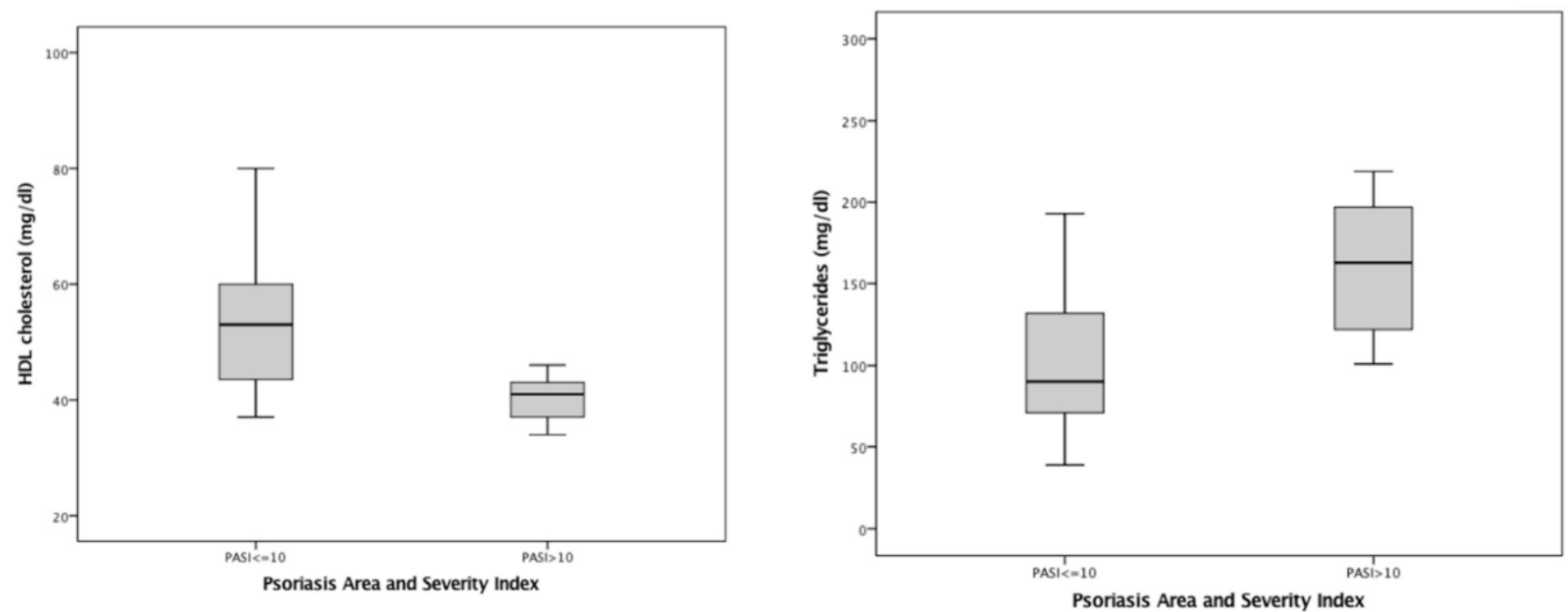

Figure 1. On the left, HDL concentrations in mild ( $54.26 \pm 14.72)$ vs moderate to severe psoriasis $(41.67 \pm 11.04)$; on the right, triglyceride levels in mild psoriasis $(113.38 \pm 66.66)$ compared to moderate to severe disease $(163.56 \pm 44.95)$. 


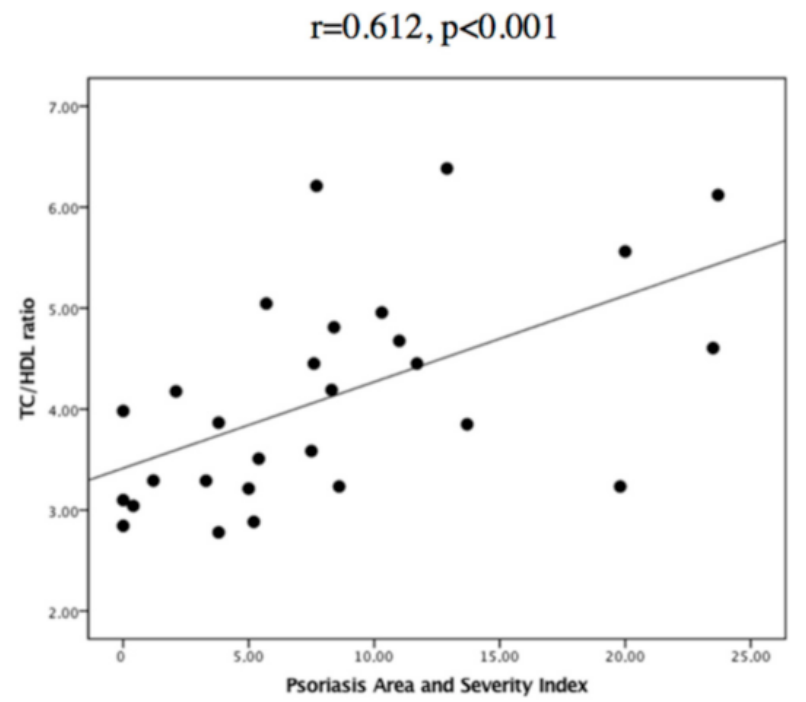

Figure 2. Graph showing association between total cholesterol/HDL ratio and psoriasis severity (estimated by PASI); Pearson's correlation used; significance level defined at $p \leq 0.05$.

\section{Discussion}

The present study intended to show a link between ACE I/D polymorphism, ACE activity, psoriasis and cardiovascular risk. Our results indicate that psoriatic patients have significantly higher ACE activity levels than controls, confirming the findings of previous studies [3].

We did not find an association between ACE genotype and the presence of psoriasis. This supports some of the previously published data where a lack of consistency in this association was predominant [5-10].

ACE activity was shown to be influenced by its genotype in both psoriatic and control subjects. A higher activity level was found in the DD genotype population, an intermediate level in the heterozygotes, and a lower one for the II population. This is in agreement with previous studies [12,38], despite it being known that the genotype only accounts for about half of the variability of the enzyme's levels [12].

The lack of difference in genotype frequencies supports the idea that some kind of stimuli maintains higher ACE activity in psoriatic patients compared to controls, regardless of their genotype. It is not yet perfectly clear why ACE levels seem to be higher in psoriatic patients. There are however a few hypotheses. Boutin et al. demonstrated, using murine models, that the skin, besides playing a known important role in the adaptation to environmental changes, is, in fact, a critical mediator of systemic responses to environmental oxygen [39]. This study showed a response to hypoxia through the epidermal transcription factor HIF- $1 \alpha$, which induces nitric oxide (NO) release. A few other studies have confirmed an association between NO, ACE levels, and endothelial dysfunction. Angiotensin is known to cause vasodilation mediated, in part, by NO release [40]. Transposing these findings to psoriasis pathophysiology, psoriatic patients' skin may be exposed to higher levels of hypoxia due to the cellular hyperproliferation characteristic of the disease. Hypoxia may subsequently lead to the release of $\mathrm{NO}$ and possibly explain, among many other factors, the observed increase in ACE activity in psoriatic patients in comparison to controls.

Using PASI as an activity index of psoriasis and comparing ACE levels in different psoriatic patients, ACE activity was numerically higher in patients with PASI $>10$. It should be noted that only nine psoriatic patients had both their PASI and ACE serum activity determined, therefore limiting a potentially significant result. Further studies are necessary as ACE could be shown to be a good biomarker for disease activity and help to identify patients requiring therapeutic adjustments.

In this study, more than the average parameters within the lipid profile were measured, such as LDL/HDL ratio, TC/HDL ratio, and non-HDL cholesterol levels, given that these 
ratios have shown a stronger association with cardiovascular risk than regular cholesterol levels alone [41-43]. As such, the correlation between ACE activity and LDL/HDL ratio may be more meaningful than previously considered. However, the lack of correlations with HDL, non-HDL and TC/HDL ratio makes it less likely that a clear association can be proven between ACE activity and cardiovascular risk.

Considering that information may be lost in the dichotomization of PASI, the continuous variable was used to study the association with lipid parameters. We observed that PASI is inversely associated with HDL cholesterol and positively correlated with LDL/HDL ratio and triglyceride levels. This indicates a decrease in HDL cholesterol with a concomitant increase in LDL/HDL ratio, TC/HDL ratio, and triglycerides with psoriasis activity. The strong correlation with TC/HDL ratio is in agreement with the fact that psoriasis severity is associated with an increase in cardiovascular disease, as the TC/HDL ratio is one of the lipid indices with a higher predictive value $[42,44,45]$.

This study has several limitations. The sample size is relatively small and it has a sex imbalance with the controls. There was an effort to adjust every test to this variable in order to decrease the possibility of biased results. In fact, there seems to be a sex influence on ACE activity with females displaying decreased ACE activity [46], however this substantiates the meaningfulness of our results as our psoriatic population consisted of around $70 \%$ females. Secondly, the recruitment of the control group from a different clinic to the psoriatic group may have been a source of bias, namely selection bias. However, both clinics have the same hospital outpatient setting and geographic location. Patients and controls were overall comparable, except for sex distribution (which was adjusted for, as mentioned), limiting any potential major bias within the analysis. Furthermore, the cardiovascular risk is also oversimplified when using only the lipid profile. It would be interesting to assess lipid function and form as psoriatic patients may have more profound disturbances in this metabolism than just merely a quantitative issue.

\section{Conclusions}

This study found an association between psoriasis and higher ACE activity levels, independent of its genotype. This increase in ACE activity suggests an oxidative stress state that is characteristic of cardiovascular disorders, since it is one of the precipitating factors in atherogenesis and endothelial disfunction. Moreover, disease activity correlated with cardiovascular risk. This could support the eventual role of ACE as a possible biomarker for disease activity and cardiovascular risk in psoriasis.

Psoriatic patients should be seen as a risk group for cardiovascular disorders and treated accordingly. New and better biomarkers for severity and for assessing this risk, such as ACE, are worthy of pursuit.

Author Contributions: Conceptualization, M.B. (Manuel Bicho) and P.F.; methodology, M.B. (Manuel Bicho); investigation, Â.G., M.B. (Matilde Bandeira) and A.C.S.; resources, Â.G. and M.B. (Manuel Bicho); patient recruitment P.F., M.R.M. and Â.G.; writing—original draft preparation, M.B. (Matilde Bandeira); writing — review and editing V.C.R., J.E.F., P.F. and M.B. (Manuel Bicho); writing-finalization, M.B. (Matilde Bandeira). All authors have read and agreed to the published version of the manuscript

Funding: This work was supported by Instituto de Saúde Ambiental, Faculdade de Medicina da Universidade de Lisboa, Portugal.

Institutional Review Board Statement: The study was conducted in accordance with the Declaration of Helsinki and has been approved by the local Ethics Committee.

Informed Consent Statement: Informed consent was obtained from all subjects involved in the study.

Data Availability Statement: The data presented in this study are available on request from the corresponding author. The data are not publicly available due to restrictions by the ethics committe.

Conflicts of Interest: The authors declare no conflict of interest. 


\section{References}

1. Langley, R.G.B. Psoriasis: Epidemiology, clinical features, and quality of life. Ann. Rheum. Dis. 2005, 64 (Suppl. 2), ii18-ii23. [CrossRef] [PubMed]

2. Nestle, F.O.; Kaplan, D.H.; Barker, J. Psoriasis. N. Engl. J. Med. 2009, 361, 496-509. [CrossRef]

3. Ryder, K.W.; Epinette, W.W.; Jay, S.J.; Ransburg, R.C.; Glick, M.R. Serum angiotensin converting enzyme activity in patients with psoriasis. Clin. Chim. Acta 1985, 153, 143-146. [CrossRef]

4. Huskić, J.; Mulabegović, N.; Alendar, F.; Ostojić, L.; Ostojić, Z.; Simić, D.; Milicević, R.; Naletilić, M. Serum and tissue angiotensin converting enzyme in patients with psoriasis. Coll. Antropol. 2008, 32, 1215-1219. [PubMed]

5. Coto-Segura, P.; Alvarez, V.; Soto-Sãjnchez, J.; Morales, B.; Coto, E.; Santos-Juanes, J. Lack of association between angiotensin I-converting enzyme insertion/deletion polymorphism and psoriasis or psoriatic arthritis in Spain. Int. J. Dermatol. 2009, 48, 1320-1323. [CrossRef]

6. Chang, Y.-C.; Wu, W.-M.; Chen, C.-H.; Lee, S.-H.; Hong, H.-S.; Hsu, L.-A. Association between the insertion/deletion polymorphism of the angiotensin I-converting enzyme gene and risk for psoriasis in a Chinese population in Taiwan. Br. J. Dermatol. 2007, 156, 642-645. [CrossRef]

7. Yang, K.; Zhang, F.; Li, F.; Su, J.; Wen, S.; Liu, Y.; Feng, D. Angiotensin-converting enzyme insertion/deletion polymorphism and susceptibility to psoriasis in a Chinese population. J. Renin-Angiotensin-Aldosterone Syst. 2013, 15, 39-43. [CrossRef]

8. Özkur, M.; Erbagci, Z.; Nacak, M.; Tuncel, A.; Alasehirli, B.; Aynacioglu, A. Association of insertion/deletion polymorphism of the angiotensin-converting enzyme gene with psoriasis. Br. J. Dermatol. 2004, 151, 792-795. [CrossRef] [PubMed]

9. Weger, W.; Hofer, A.; Wolf, P.; El-Shabrawi, Y.; Renner, W.; Kerl, H.; Salmhofer, W. The angiotensin-converting enzyme insertion/deletion and the endothelin -134 3A/4A gene polymorphisms in patients with chronic plaque psoriasis. Exp. Dermatol. 2007, 16, 993-998. [CrossRef] [PubMed]

10. Veletza, S.; Karpouzis, A.; Giassakis, G.; Caridha, R.; Papaioakim, M. Assessment of insertion/deletion polymorphism of the angiotensin converting enzyme gene in psoriasis. J. Dermatol. Sci. 2008, 49, 85-87. [CrossRef]

11. Rigat, B.; Hubert, C.; Corvol, P.; Soubrier, R. PCR detection of the insertion/deletion polymorphism of the human angiotensin converting enzyme gene (DCP1) (dipeptidyl carboxypeptidase 1). Nucleic Acids Res. 1992, 20, 1433. [CrossRef] [PubMed]

12. Rigat, B.; Hubert, C.; Alhenc-Gelas, F.; Cambien, F.; Corvol, P.; Soubrier, F. An insertion/deletion polymorphism in the angiotensin I-converting enzyme gene accounting for half the variance of serum enzyme levels. J. Clin. Investig. 1990, 86, 1343-1346. [CrossRef] [PubMed]

13. Haznedaroglu, I.C.; Öztürk, M. Towards the understanding of the local hematopoietic bone marrow renin-angiotensin system Int. J. Biochem. Cell Biol. 2003, 35, 867-880. [CrossRef]

14. Fleming, I. Signaling by the Angiotensin-Converting Enzyme. Circ. Res. 2006, 98, 887-896. [CrossRef]

15. Qian, C.; Schoemaker, R.G.; van Gilst, W.; Roks, A.J.M. The role of the renin-angiotensin-aldosterone system in cardiovascular progenitor cell function. Clin. Sci. 2009, 116, 301-314. [CrossRef] [PubMed]

16. Guimarães, P.B.; Alvarenga, C.; Siqueira, P.D.; Paredes-Gamero, E.J.; Sabatini, R.A.; Morais, R.L.; Reis, R.I.; Santos, E.L.; Teixeira, L.G.; Casarini, D.E.; et al. Angiotensin II Binding to Angiotensin I-Converting Enzyme Triggers Calcium Signaling. Hypertension 2011, 57, 965-972. [CrossRef]

17. Yeung, H.; Takeshita, J.; Mehta, N.N.; Kimmel, S.E.; Ogdie, A.; Margolis, D.J.; Shin, D.B.; Attor, R.; Troxel, A.; Gelfand, J.M. Psoriasis severity and the prevalence of major medical comorbidity. JAMA Dermatol. 2013, 149, 1173-1179. [CrossRef] [PubMed]

18. Yim, K.M.; Armstrong, A.W. Updates on cardiovascular comorbidities associated with psoriatic diseases: Epidemiology and mechanisms. Rheumatol. Int. 2016, 37, 97-105. [CrossRef] [PubMed]

19. Gottlieb, A.B.; Dann, F. Comorbidities in patients with psoriasis. Am. J. Med. 2009, 122, 1150.e1-1150.e9. [CrossRef] [PubMed]

20. Lowes, M.A.; Suárez-Fariñas, M.; Krueger, J.G. Immunology of psoriasis. Annu. Rev. Immunol. 2014, 32, 227-255. [CrossRef] [PubMed]

21. Mahil, S.K.; Capon, F.; Barker, J.N. Update on psoriasis immunopathogenesis and targeted immunotherapy. Semin. Immunopathol. 2015, 38, 11-27. [CrossRef]

22. Armstrong, A.W.; Voyles, S.V.; Armstrong, E.J.; Fuller, E.N.; Rutledge, J.C. A tale of two plaques: Convergent mechanisms of T-cell-mediated inflammation in psoriasis and atherosclerosis. Exp. Dermatol. 2011, 20, 544-549. [CrossRef] [PubMed]

23. Akhyani, M.; Ehsani, A.; Robati, R.; Robati, A. The lipid profile in psoriasis: A controlled study. J. Eur. Acad. Dermatol. Venereol. 2007, 21, 1330-1332. [CrossRef] [PubMed]

24. Tekin, N.S.; Tekin, I.O.; Barut, F.; Sipahi, E.Y. Accumulation of oxidized low-density lipoprotein in psoriatic skin and changes of plasma lipid levels in psoriatic patients. Mediat. Inflamm. 2006, 2007, 1-5. [CrossRef]

25. Mallbris, L.; Granath, F.; Hamsten, A.; Ståhle, M. Psoriasis is associated with lipid abnormalities at the onset of skin disease. J. Am. Acad. Dermatol. 2006, 54, 614-621. [CrossRef]

26. Neimann, A.L.; Shin, D.B.; Wang, X.; Margolis, D.J.; Troxel, A.; Gelfand, J. Prevalence of cardiovascular risk factors in patients with psoriasis. J. Am. Acad. Dermatol. 2006, 55, 829-835. [CrossRef]

27. Moon, Y.-S.; Kim, D.-H.; Song, D.-K. Serum tumor necrosis factor- $\alpha$ levels and components of the metabolic syndrome in obese adolescents. Metabolism 2004, 53, 863-867. [CrossRef]

28. Fantuzzi, G. Adipose tissue, adipokines, and inflammation. J. Allergy Clin. Immunol. 2005, 115, 911-919. [CrossRef] [PubMed] 
29. Jung, U.J.; Choi, M.-S. Obesity and its metabolic complications: the role of adipokines and the relationship between obesity, inflammation, insulin resistance, dyslipidemia and nonalcoholic fatty liver disease. Int. J. Mol. Sci. 2014, 15, 6184-6223. [CrossRef] [PubMed]

30. Mehta, N.N.; Li, R.; Krishnamoorthy, P.; Yu, Y.; Farver, W.; Rodrigues, A.; Raper, A.; Wilcox, M.; Baer, A.; DerOhannesian, S.; et al. Abnormal lipoprotein particles and cholesterol efflux capacity in patients with psoriasis. Atherosclerosis 2012, 224, $218-221$. [CrossRef]

31. Yu, Y.; Sheth, N.; Krishnamoorthy, P.; Saboury, B.; Raper, A.; Baer, A.; Ochotony, R.; Doveikis, J.; Derohannessian, S.; Van Voorhees, A.S.; et al. Aortic vascular inflammation in psoriasis is associated with HDL particle size and concentration: A pilot study. Am. J. Cardiovasc. Dis. 2012, 2, 285-292.

32. Salahuddin, T.; Natarajan, B.; Playford, M.P.; Joshi, A.A.; Teague, H.; Masmoudi, Y.; Selwaness, M.; Chen, M.Y.; Bluemke, D.A.; Mehta, N.N. Cholesterol efflux capacity in humans with psoriasis is inversely related to non-calcified burden of coronary atherosclerosis. Eur. Heart J. 2015, 36, 2662-2665. [CrossRef] [PubMed]

33. Husain, K.; Hernandez, W.; Ansari, R.A.; Ferder, L. Inflammation, oxidative stress and renin angiotensin system in atherosclerosis. World J. Biol. Chem. 2015, 6, 209-217. [CrossRef]

34. Stocker, R.; Keaney, J.F., Jr. Role of oxidative modifications in atherosclerosis. Physiol. Rev. 2004, 84, 1381-1478. [CrossRef]

35. Cosenso-Martin, L.N.; Vaz-De-Melo, R.O.; Pereira, L.R.; Cesarino, C.B.; Yugar-Toledo, J.C.; Cipullo, J.P.; Pinhel, M.A.D.S.; Souza, D.R.S.; Vilela-Martin, J.F. Angiotensin-converting enzyme insertion/deletion polymorphism, 24-h blood pressure profile and left ventricular hypertrophy in hypertensive individuals: A cross-sectional study. Eur. J. Med. Res. 2015, 20, 1-9. [CrossRef]

36. Dhar, S.; Ray, S.; Dutta, A.; Sengupta, B.; Chakrabarti, S. Polymorphism of ACE gene as the genetic predisposition of coronary artery disease in Eastern India. Indian Heart J. 2012, 64, 576-581. [CrossRef] [PubMed]

37. Mrowietz, U.; Kragballe, K.; Reich, K.; Spuls, P.; Griffiths, C.E.M.; Nast, A.; Franke, J.; Antoniou, C.; Arenberger, P.; Balieva, F.; et al. Definition of treatment goals for moderate to severe psoriasis: A European consensus. Arch. Dermatol. Res. 2010, 303, 1-10. [CrossRef]

38. Danser, A.J.; Schalekamp, M.A.; Bax, W.A.; Brink, A.M.V.D.; Saxena, P.R.; Riegger, G.A.; Schunkert, H. Angiotensin-converting enzyme in the human heart. Circulation 1995, 92, 1387-1388. [CrossRef]

39. Boutin, A.T.; Weidemann, A.; Fu, Z.; Mesropian, L.; Gradin, K.; Jamora, C.; Wiesener, M.; Eckardt, K.-U.; Koch, C.J.; Ellies, L.G.; et al. Epidermal sensing of oxygen is essential for systemic hypoxic response. Cell 2008, 133, 223-234. [CrossRef]

40. Sampaio, W.O.; Souza dos Santos, R.A.; Faria-Silva, R.; da Mata Machado, L.T.; Schiffrin, E.L.; Touyz, R.M. Angiotensin-(1-7) through receptor mas mediates endothelial nitric oxide synthase activation via akt-dependent pathways. Hypertension 2007, 49, 185-192. [CrossRef]

41. Millán, J.; Pintó, X.; Muñoz, A.; Zúñiga, M.; Rubiés-Prat, J.; Pallardo, L.F.; Masana, L.; Mangas, A.; Hernández-Mijares, A.; González-Santos, P.; et al. Lipoprotein ratios: Physiological significance and clinical usefulness in cardiovascular prevention. Vasc. Health Risk Manag. 2009, 5, 757-765. [PubMed]

42. Kinosian, B.; Glick, H.; Garland, G. Cholesterol and coronary heart disease: Predicting risks by levels and ratios. Ann. Intern. Med. 1994, 121, 641-647. [CrossRef] [PubMed]

43. Ascaso, J.F.; Santos, P.G.; Mijares, A.H.; Rojas, A.M.; Masana, L.; Millan, J.; Pallardo, L.F.; Pedrobotet, J.; Jimenez, F.P.; Pinto, X.; et al. Management of dyslipidemia in the metabolic syndrome. Am. J. Cardiovasc. Drugs 2007, 7, 39-58. [CrossRef] [PubMed]

44. Shai, I.; Rimm, E.B.; Hankinson, S.E.; Curhan, G.; Manson, J.E.; Rifai, N.; Stampfer, M.J.; Ma, J. multivariate assessment of lipid parameters as predictors of coronary heart disease among postmenopausal women. Circulation 2004, 110, 2824-2830. [CrossRef] [PubMed]

45. Hsia, S.H.; Pan, D.; Berookim, P.; Lee, M.L. A Population-based, cross-sectional comparison of lipid-related indexes for symptoms of atherosclerotic disease. Am. J. Cardiol. 2006, 98, 1047-1052. [CrossRef] [PubMed]

46. Zapater, P.; Novalbos, J.; Gallego-Sandín, S.; Hernández, F.T.; Abad-Santos, F. Gender differences in angiotensin-converting enzyme (ACE) activity and inhibition by enalaprilat in healthy volunteers. J. Cardiovasc. Pharmacol. 2004, 43, 737-744. [CrossRef] 